Ks. Marek Jodkowski*

Wydziat Teologii Uniwersytetu Warmińsko-Mazurskiego w Olsztynie

\title{
PARAFIA KATOLICKA W OSTRÓDZIE W XIX I PIERWSZEJ POLOWIE XX WIEKU
}

Stowa klucze:

diaspora katolicka, diecezja chełmińska, diecezja warmińska, budownictwo sakralne, budownictwo kościelne, Prusy Wschodnie, Prusy Zachodnie

Treść:

I. Geneza i rozwój parafii katolickiej

II. Placówka sióstr elżbietanek w Ostródzie

III. Struktura ludnościowa

IV. Wybrane aspekty duszpasterskie

V. Finanse parafii

\section{GENEZA I ROZWÓJ PARAFII KATOLICKIEJ}

W pierwszej połowie XIX wieku wskutek przemian społecznopolitycznych ludność katolicka zaczęła osiedlać się na obszarach Prus zdominowanych przez ewangelików. Dzięki bulli cyrkumskrypcyjnej Piusa VII z 16 lipca 1821 roku rozpoczynającej się od słów De salute animarum dawną diecezję pomezańską poddano opiece włodarzy diecezji chełmińskiej i warmińskiej. Odtąd diaspora katolicka stała się widocznym elementem w strukturze społecznej Mazur oraz innych krain usytuowanych w Prusach Wschodnich i Zachodnich ${ }^{1}$.

Historia parafii katolickiej w Ostródzie nie doczekała się jeszcze pełnej monografii w języku polskim. Cenne informacje dotyczące jej genezy wnio-

\footnotetext{
${ }^{*}$ Ks. dr Marek Jodkowski, historyk Kościoła, historyk sztuki i archiwista; adiunkt w Katedrze Historii Kościoła i Dziedzictwa Kulturowego na Wydziale Teologii Uniwersytetu Warmińsko-Mazurskiego w Olsztynie.

${ }^{1}$ Por. A. Kopiczko, Duchowieństwo katolickie diecezji warmińskiej w latach 1821-1945, cz. 1: Studium prozopograficzne, Olsztyn 2004, s. 15; R. Traba, Kościół rzymskokatolicki, w: Historia Pomorza, t. 4 (1850-1918), cz. 2: Polityka i kultura, red. S. Salmonowicz, Toruń 2002, s. 473 .
} 
sło polskojęzyczne wydanie przedwojennych Dziejów Ostródy ${ }^{2}$ autorstwa Johannesa Müllera. Na szczególną uwagę zasługuje także publikacja Andrzeja Kopiczko ${ }^{3}$, który ukazał znaczenie parafii i świątyni ostródzkiej na tle kościołów jubileuszowych 2000 roku w archidiecezji warmińskiej. Warto również odnieść się do wydanych w języku niemieckim badań $\mathrm{K}$. Bürgera ${ }^{4}$, który chronologicznie zestawił wydarzenia z historii Kościoła katolickiego w Ostródzie. Powyższe prace nie wyczerpują jednak opisu złożonych dziejów wspomnianej placówki duszpasterskiej. Aby uzupełnić je o kolejne aspekty, należy skoncentrować się przede wszystkim na analizie archiwaliów znajdujących się w Bonifatiuswerk w Paderborn, które były częścią archiwum zarządu generalnego Stowarzyszenia św. Bonifacego. Instytucja ta wspierała rozwój diaspory katolickiej, dotując inwestycje budowlane i pensje pracowników kościelnych.

W Ostródzie pierwszą Mszę św. od okresu reformacji odprawiono w $1834 \mathrm{roku}^{5}$. Od tego czasu proboszcz z Grabowa, oddalonego 3 mile od Ostródy, celebrował dwa razy w ciagu roku nabożeństwa dla żołnierzy katolickich stacjonujących w tej miejscowości ${ }^{6}$. Zarówno odległość od innych stacji misyjnych, jak i potrzeby religijne katolików spowodowały, że 11 marca 1853 roku komitet diecezjalny Stowarzyszenia św. Bonifacego w Pelplinie powziął decyzję mającą na celu wsparcie ostródzkiej społeczności katolickiej ${ }^{7}$. Warto nadmienić, że tereny diecezji chełmińskiej usytuowane na Mazurach traktowano wówczas jako obszary misyjne ${ }^{8}$.

Pierwszym duszpasterzem w Ostródzie został ustanowiony 27 września 1853 roku Stephan Keller. Posługę kapłańską w opisywanym mieście zainaugurował Mszą św. celebrowaną 23 października 1853 roku w wynajętym pomieszczeniu9. Na marginesie należy dodać, że osiem dni później zmarł z powodu następstw wywołanych przez cholerę ostródzki adwokat Ruland, który został pochowany z katolickim rytuałem na cmentarzu ewangelickim. Już 21 marca 1853 roku przesłał on prośbę do kanonika chełmińskiego Eduarda Herzoga, założyciela diecezjalnego Stowarzyszenia św. Bonifacego

\footnotetext{
${ }^{2}$ Por. J. Müller, Dzieje Ostródy, tłum. D. Krzywicka-Ka endler, Ostróda 2010.

${ }^{3}$ Por. A. Kopiczko, Porta Domini. Kościoly jubileuszowe i sanktuaria Świętego Krzyża w archidiecezji warmińskiej, Olsztyn 2002.

${ }^{4}$ Por. K. Bürger, Das katholische Kirchenwesen im Kreis Osterode (2), „Unsere Ermländische Heimat" 1979, nr 1, s. 2-3.

${ }^{5}$ Por. W. Barczewski, Nowe kościoly katolickie na Mazurach, Olsztyn ${ }^{2}$ 1925, s. 96; A. Kopiczko, Porta Domini. Kościoły jubileuszowe i sanktuaria Świętego Krzyża w archidiecezji warmińskiej, dz. cyt., s. 92.

${ }^{6}$ Por. K. Bürger, Das katholische Kirchenwesen im Kreis Osterode (2), dz. cyt., s. 2; „Rocznik Diecezji Warmińskiej” 1985, Olsztyn 1985, s. 399; Archiwum Zarządu Generalnego Stowarzyszenia św. Bonifacego w Paderborn (dalej cyt. Arch. Paderborn), Teczka: Osterode (3.01.1863).

${ }^{7}$ Por. K. Bürger, Das katholische Kirchenwesen im Kreis Osterode (2), dz. cyt., s. 2.

${ }^{8}$ Por. H. Mross, Stownik biograficzny kapłanów diecezji chetmińskiej wyświęconych w latach 1821-1920, Pelplin 1995, s. 102.

${ }^{9}$ Por. K. Bürger, Das katholische Kirchenwesen im Kreis Osterode (2), dz. cyt., s. 2.
} 
w Pelplinie, o skierowanie duchownego katolickiego do Ostródy. Swój list zakończył słowami: „Nie mogę znieść myśli, że mnie - urodzonego i wychowanego w wierze katolickiej - ma spotkać okropny los zakończenia doczesnego życia bez pociechy, jaką daje nasza religia - niech Bóg do tego nie dopuści”10. Od 1 października 1854 roku nabożeństwa sprawowano w jednym z pomieszczeń zamkowych ${ }^{11}$, o co zabiegał 17 czerwca 1853 roku biskup Anastazy Sedlag w prośbie skierowanej do władz państwowych ${ }^{12}$.

Ksiądz S. Keller starał się nie tylko o rozwój duszpasterskiego oblicza stacji misyjnej, ale również dbał o wychowanie dzieci i młodzieży. Założył 31 maja 1855 roku prywatną szkołę katolicka, która prowadził przez kilka lat ${ }^{13}$. W początkowym okresie jej działalności uczęszczało na zajęcia 34 dzieci $^{14}$. Należy podkreślić, że 2 października 1860 roku wspomnianej placówce oświatowej nadano charakter publiczny. Zgodnie z decyzją władz prowincjonalnych w Królewcu z 24 kwietnia 1874 roku klasę katolicką połączono z dwuklasową ludową szkołą ewangelicką. Nowa instytucja stała się w rzeczywistości wielowyznaniową szkołą z trzema klasami ${ }^{15}$. Od 1863 roku katolickim nauczycielem i jednocześnie organistą w Ostródzie był August Kalinowski, który otrzymywał do 1868 roku wypłatę o wartości 204 talarów (m.in. jako nauczyciel - 152 talary i jako organista - 40 talarów). W tym czasie najmłodszy luterański nauczyciel zatrudniony w Ostródzie pobierał 220 talarów $^{16}$.

Jednym z największych zadań stojących przed ostródzkim duszpasterzem była budowa świątyni. Projekt kościoła opracował koloński architekt Vinzenz Statz. Kamień węgielny pod nowy obiekt sakralny został położony 28 sierpnia 1856 roku przez ks. S. Kellera, któremu asystowało ośmiu innych duchownych. Poświęcenie kościoła miało miejsce 20 grudnia 1857 roku, zresztą bez uroczystej oprawy ${ }^{17}$. W 1863 roku podano wymiary świątyni: długość -70 stóp, szerokość - 50 stóp i wysokość - 32 stopy. Paramenty liturgiczne do ostródzkiej placówki ufundowało już w 1854 roku Stowarzyszenie Kobiet im. św. Bonifacego w Münster (Bonifazius-Frauen-Verein). W 1859 roku dzięki

\footnotetext{
${ }^{10}$ Schematismus des Bistums Culm mit dem Bischofssitze in Pelplin 1904, Pelplin 1904, s. 396 (por. H. Mross, Stownik biograficzny kapłanów diecezji chetmińskiej wyświęconych w latach 1821-1920, dz. cyt., s. 102).

${ }^{11}$ Por. K. Bürger, Das katholische Kirchenwesen im Kreis Osterode (2), dz. cyt., s. 2.

12 Por. Schematismus des Bistums Culm mit dem Bischofssitze in Pelplin 1904, dz. cyt., s. 396.

${ }^{13}$ Por. K. Bürger, Das katholische Kirchenwesen im Kreis Osterode (2), dz. cyt., s. 2; Schematismus des Bistums Culm mit dem Bischofssitze in Pelplin 1904, dz. cyt., s. 396.

${ }^{14}$ Por. Arch. Paderborn, Teczka: Osterode (3.01.1880).

${ }^{15}$ Por. tamże, Statistischer Bericht über die Missions-Pfarrei Osterode pro 1874 (3.01.1880).

${ }^{16}$ Por. tamże (24.04.1868).

${ }^{17}$ Por. K. Bürger, Das katholische Kirchenwesen im Kreis Osterode (2), dz. cyt., s. 2; A. Kopiczko, Porta Domini. Kościoły jubileuszowe $i$ sanktuaria Świętego Krzyża w archidiecezji warmińskiej, dz. cyt., s. 92; Schematismus des Bistums Culm mit dem Bischofssitze

in Pelplin 1904, dz. cyt., s. 396; „Rocznik Diecezji Warmińskiej” 1985, dz. cyt., s. 399.
} 
ofiarności mieszkańców stacji misyjnej oraz dobroczyńców zakupiono trzy dzwony, małe organy oraz parcele pod cmentarz katolicki ${ }^{18}$. Zdaniem proboszcza ostródzkiego Wladislausa Fischoedera od 1857 do 1912 roku nie przeprowadzono w świątyni żadnego gruntownego remontu ${ }^{19}$.

Niemal bezpośrednio po wybudowaniu kościoła podjęto kroki zmierzające do ustanowienia w Ostródzie samodzielnej parafii. Odpowiednią decyzję w tej sprawie wydały władze diecezji chełmińskiej 10 lutego 1860 roku Potwierdzenie ze strony instytucji państwowych otrzymano 11 kwietnia 1861 roku $^{20}$. Kolejny proboszcz parafii - Theophil von Gierszewski przystapił zapewne do budowy nowego domu parafialnego, skoro w 1868 roku murowana plebania znajdowała się już w stanie surowym ${ }^{21}$. Oprócz proboszcza zamieszkał w niej również organista. Warto nadmienić, że obok kościoła znajdował się ogród oraz stajnia ${ }^{22}$. Własnością parafii w tamtym okresie był również dom ze stajnią oraz 4 morgi ziemi położone w Turznicy oddalonej półtorej mili od Ostródy. W tamtejszym budynku mieszkalnym erygowano katolicką szkołę. Ponadto proboszcz ostródzki sprawował w opisywanym miejscu cyklicznie nabożeństwa. Należy dodać, że wspomniana nieruchomość została zakupiona przez Stowarzyszenie św. Bonifacego ${ }^{23}$.

Już pod koniec XIX wieku powierzchnia kościoła nie odpowiadała wzrastającej liczbie wiernych ${ }^{24}$. $Z$ tego powodu brano pod uwagę dwa rozwiązania: rozbudowę dotychczasowej świątyni bądź - z uwagi na niekorzystne ukształtowanie terenu - budowę nowego obiektu sakralnego. Koszt rozbudowy kościoła szacowano wówczas na 84000 marek $^{25}$. Jednak od 1898 roku do początku 1900 roku zdołano zebrać na ten cel jedynie 1600 marek $^{26}$. Dzięki ofiarności wiernych oraz pomocy biskupa chełmińskiego zgromadzono w połowie 1900 roku -4000 marek w kasie budowlanej ${ }^{27}$. Do 1912 roku kapitał budowlany opiewał na 72000 marek. Wprawdzie wartość kosztorysu budowy sporządzonego przez architekta Fritza Heitmanna w 1907 roku wynosiła 119800 marek, jednak realne koszty inwestycji do czasu jej rozpoczęcia wzrosły do 135000 marek. Zgodnie z tradycją 1/3 kosztów budowy miały opłacić władze patronalne, w tym przypadku biskup chełmiński, jednak stan kasy diecezjalnej nie pozwalał na tak duże wydat$\mathrm{ki}^{28}$. Ze względu na trudności finansowe ostródzkiej parafii już 12 grudnia

\footnotetext{
${ }^{18}$ Por. Arch. Paderborn, Teczka: Osterode (3.01.1863).

${ }^{19}$ Por. tamże (25.01.1912).

${ }^{20}$ Por. K. Bürger, Das katholische Kirchenwesen im Kreis Osterode (2), dz. cyt., s. 2; A. Kopiczko, Porta Domini. Kościoly jubileuszowe i sanktuaria Świętego Krzyża w archidiecezji warmińskiej, dz. cyt., s. 92; J. Müller, Dzieje Ostródy, dz. cyt., s. 422.

${ }^{21}$ Por. Arch. Paderborn, Teczka: Osterode (1868).

${ }^{22}$ Por. tamże (5.04.1872).

${ }^{23}$ Por. tamże.

${ }^{24}$ Por. tamże (12.02.1900).

${ }^{25}$ Por. tamże, Missionsbericht vom Jahre 1902.

${ }^{26}$ Por. tamże (12.02.1900).

${ }^{27}$ Por. tamże (28.07.1900).

${ }^{28}$ Por. tamże (25.01.1912).
} 
1911 roku postanowiono, że na wspomniane cele budowlane zostanie wzięta pożyczka, która miała pokryć $2 / 3$ brakującej sumy. Zdecydowano także, że przedstawiciele opisywanej placówki ponownie wystosują prośbę do władz biskupich o zwyczajową donację patronalną 29 .

Dalsze prace budowlane przy ostródzkiej świątyni miały miejsce od jesieni 1912 do 1913 roku. W tym czasie wydłużono nawę kościoła o kolejne dwa przęsła, dobudowano prezbiterium wraz z aneksami, sterczyny wieńczące szczyty oraz wieżę. Projekt wspomnianych prac przygotował, wzorując się na wcześniej sporządzonych przez siebie szkicach kościoła w Biesowie, architekt licznych obiektów sakralnych w diecezji warmińskiej - Fritz Heitmann z Królewca ${ }^{30}$.

Ostatecznie świątyni nadano charakter neogotycki, w stylu orientowanych kościołów murowanych z czerwonej cegły na kamiennej podmurówce. Trójnawowe wnętrze halowe zamknięto krótkim prezbiterium z przylegającymi do niego aneksami. Od strony południowej usytuowano na planie kwadratu wieżę o wysokości $54 \mathrm{~m}$, zwieńczoną spiczastym dachem miedzianym, z kruchtą w przyziemiu. Sklepieniom nawy głównej nadano kształt gwiazdy czteroramiennej, natomiast $w$ nawach bocznych zaprojektowano sklepienia krzyżowe. Nawy kościoła oddzielono filarami opartymi na monolitowych, granitowych kolumnach. Drewniany chór muzyczny wybudowano po zachodniej stronie świątyni.

Po rozbudowie ostródzki kościół ozdobiono witrażowymi oknami wykonanymi przez Georga Schneidera z Regensburga w 1913 roku, które zostały ufundowane przez ostródzkiego proboszcza Wladislausa Fischoedera, organizacje katolickie działające w parafii (Towarzystwo św. Cecylii, Towarzystwo Pogrzebowe, Towarzystwo św. Elżbiety, Związek Czeladniczy), a także prywatnych fundatorów (m.in. kupca Eduarda Herrmanna - członka zarządu kościelnego) $)^{31}$.

Warto wspomnieć, że podczas przebudowy niedzielne Msze św. odbywały się w sali gimnastycznej, natomiast niedzielne nabożeństwa okresowe oraz Msze św. w ciagu tygodnia sprawowano w kaplicy sióstr elżbietanek przy ówczesnej ul. Schillera 4, naprzeciwko budującego się kościoła ${ }^{32}$.

W 1904 roku poza Ostródą katolickie lekcje religii (dwie godziny w ciągu tygodnia) odbywały się w Idzbarku, Kajkowie, Miłomłynie, Ostrowinie,

\footnotetext{
${ }^{29}$ Por. tamże.

${ }^{30}$ Por. Archiwum Państwowe w Olsztynie, 367/140, k. 10; K. Bürger, Das katholische Kirchenwesen im Kreis Osterode (2), dz. cyt., s. 2; A. Kopiczko, Porta Domini. Kościoły jubileuszowe i sanktuaria Świętego Krzyża w archidiecezji warmińskiej, dz. cyt., s. 93. Por. także M. Jodkowski, Budownictwo sakralne diecezji warmińskiej $w$ latach 18211945, Olsztyn 2011, s. 201-203; Arch. Paderborn, Teczka: Osterode (25.01.1912).

${ }^{31}$ Por. K. Bürger, Das katholische Kirchenwesen im Kreis Osterode (2), dz. cyt., s. 2; A. Kopiczko, Porta Domini. Kościoły jubileuszowe i sanktuaria Świętego Krzyża w archidiecezji warmińskiej, dz. cyt., s. 97; J. Müller, Dzieje Ostródy, dz. cyt., s. 423.

${ }_{32}$ Por. K. Bürger, Das katholische Kirchenwesen im Kreis Osterode (2), dz. cyt., s. 2.
} 
Szczepankowie, Turznicy, Tyrowie i Zwierznie ${ }^{33}$. Z zestawień statystycznych parafii z 1916 roku wynikało, że proboszcz prowadził lekcje religii w ostródzkim gimnazjum i liceum, natomiast w szkole podstawowej - świecki nauczyciel wyznania katolickiego ${ }^{34}$. W innych miejscowościach należących do parafii lekcji religii udzielał dojeżdżający nauczyciel (zwany wówczas nauczycielem wędrownym). Warto podkreślić, że w 1914 roku ostródzcy katolicy skierowali do Ministerstwa Nauki, Sztuki i Edukacji w Berlinie prośbę o erygowanie katolickiej szkoły miejskiej. Po otrzymaniu zezwolenia ze strony władz państwowych, jak i miejskich zaplanowano w 1915 roku przeprowadzenie odpowiednich prac adaptacyjnych, jednak wojna pokrzyżowała wspomniane zamiary. W tym czasie proboszcz parafii ostródzkiej dostrzegał potrzebę budowy kościoła filialnego w Miłomłynie, gdzie od 1915 roku sprawowano raz w miesiącu nabożeństwa w miejscowej sali tanecznej ${ }^{35}$.

Kościół ostródzki ku czci Niepokalanego Poczęcia Najświętszej Maryi Panny konsekrował 1 czerwca 1923 roku biskup warmiński Augustyn Bludau $^{36}$. W latach 1924-1925 przeprowadzono renowację świątyni. Wymalowano jej wnętrze oraz ufundowano nowy ołtarz boczny dedykowany Najświętszemu Sercu Pana Jezusa ${ }^{37}$.

W parafii ostródzkiej pracowali następujący duszpasterze, którzy pełnili urząd kuratusa, komendariusza bądź proboszcza ${ }^{38}$ : Stephan Keller (od 27 września 1853); Joseph von Wysocki (od 1860); Theophil von Gierszewski (od 17 listopada 1863); Franz Gieszka (od 26 czerwca 1872; proboszcz od 23 czerwca 1873); Anton Muchowski (od 29 maja 1888); Heinrich Cajetan Ossowski (od 6 października 1893); Adolf Johannes Wegner (od 28 listopada 1899); Joseph Szydzik (od 19 lutego 1903); Franz Herrmann (komendariusz od 1905, proboszcz od 1 sierpnia 1907); Wladislaus Fischoeder (komendariusz od 1909 roku, proboszcz od 27 sierpnia 1910); Georg Wedig (kuratus od 25 listopada 1919); Bernhard Gischarowski (od 14 marca 1929); Johannes Grunwald (od 26 lipca 1939), Paul Dreyer (od 11 sierpnia 1939). We wspomnianej placówce pracowali także wikariusze. Ich zatrudnienie w Ostródzie wynikało nie tylko ze wzrastających potrzeb duszpasterskich, ale także z konieczności obsługiwania istniejącego od 1903 roku kościoła dojazdowego w Szczepankowie ${ }^{39}$.

\footnotetext{
${ }^{33}$ Por. Schematismus des Bistums Culm mit dem Bischofssitze in Pelplin 1904, dz. cyt., s. 398.

${ }^{34}$ Por. Arch. Paderborn, Teczka: Osterode, Missionsbericht 1916.

${ }^{35}$ Por. tamże.

${ }^{36}$ Por. „Rocznik Diecezji Warmińskiej” 1985, dz. cyt., s. 399. Od grudnia 1922 roku parafia ostródzka została przyłączona do diecezji warmińskiej (por. tamże).

${ }^{37}$ Por. K. Bürger, Das katholische Kirchenwesen im Kreis Osterode (2), dz. cyt., s. 2.

${ }^{38}$ Por. tamże, s. 3; H. Mross, Stownik biograficzny kapłanów diecezji chelmińskiej wyświęconych w latach 1821-1920, dz. cyt., s. 68, 77, 130, 211, 228, 326, 348, 372; A. Kopiczko, Duchowieństwo katolickie diecezji warmińskiej w latach 1821-1945, cz. 2: Stownik, Olsztyn 2003, s. 58, 78, 91.

${ }^{39}$ Por. Arch. Paderborn, Teczka: Osterode (25.01.1912).
} 


\section{PLACÓWKA SIÓSTR ELŻBIETANEK W OSTRÓDZIE}

Od 1 lipca 1900 roku rozpoczęły swoją posługę w ostródzkiej parafii siostry zakonne - elżbietanki śląskie, zwane szarymi. Charyzmatem tego zgromadzenia była pielęgnacja chorych $w$ domach bez względu na ich sytuację materialną $\mathrm{i}$ wyznaniową ${ }^{40}$. Oprócz realizacji zadań nakreślonych $\mathrm{w}$ charyzmacie elżbietanki zajmowały się w Ostródzie prowadzeniem ochronki, którą w późniejszym czasie określano jako przedszkole. W 1904 roku zgromadzenie pozyskało od parafii parcelę z przeznaczeniem na pomieszczenia klasztorne, przypuszczalnie przy ówczesnej ul. Schillera 4. Najczęściej w opisywanym mieście mieszkało pięć sióstr zakonnych, z których jedna zajmowała się prowadzeniem przedszkola, a trzy opiekowały się chorymi ${ }^{41}$.

W 1926 roku przebywało we wspomnianym przedszkolu 64 dzieci, z których dwoje było sierotami. Z racji uczęszczania do tej placówki 45 dzieci miało opłacone czesne, natomiast bez opłaty pozostawało 19 podopiecznych. Warto wspomnieć, że średnia wieku dzieci uczestniczących w zajęciach w opisywanej instytucji wynosiła 4-6 lat ${ }^{42}$. W 1931 roku do przedszkola uczęszczało ok. 65 dzieci. Do dyspozycji dzieci, oprócz pomieszczenia w budynku klasztornym, przeznaczono plac zabaw wraz z dość długą, zadaszoną werandą ${ }^{43}$.

\section{STRUKTURA LUDNOŚCIOWA}

W 1868 roku liczba katolików w Ostródzie wynosiła 401, zaś w pozostałych 105 miejscowościach należących do opisywanej placówki duszpasterskiej - 742. W ostatnim semestrze 1867 roku uczęszczało do szkoły 67 katolickich uczniów, z czego 28 wywodziło się z rodzin mieszanych. Oprócz tego 24 dzieci chodziło do prywatnej szkoły katolickiej w Turznicy ${ }^{44}$. W 1872 roku katolików należących do ostródzkiej parafii było ok. 1170 (w tym 420 w Ostródzie) ${ }^{45}$, natomiast w 1878 roku $-1219^{46}$. Nie wiadomo jednak, co stanowiło kryterium powyższych zestawień statystycznych, skoro rok później w parafii miało mieszkać 1127 katolików, z czego 445 w Ostródzie. Być może do liczby katolików ostródzkich dodawano stacjonujących żołnierzy wyznania katolickiego. W 1879 roku odnotowano 25 katolickich rodzin mieszkających w parafii. Dzieci w wieku szkolnym było 118 (w tym w Ostródzie -71$)^{47}$. W 1883 roku liczba katolików należących do parafii

${ }^{40}$ Por. A. Kaczmarek, Elżbietanki ślaskie, w: Encyklopedia Katolicka, t. IV, red. R. Łukaszyk, L. Bieńkowski i F. Gryglewicz, Lublin 1985, kol. 919-920.

${ }^{41}$ Por. K. Bürger, Das katholische Kirchenwesen im Kreis Osterode (2), dz. cyt., s. 3.

${ }^{42}$ Por. Arch. Paderborn, Teczka: Osterode, Missionsbericht 1926.

${ }^{43}$ Por. K. Bürger, Das katholische Kirchenwesen im Kreis Osterode (2), dz. cyt., s. 3.

${ }^{44}$ Por. Arch. Paderborn, Teczka: Osterode (1868).

${ }^{45}$ Por. tamże (5.04.1872).

${ }^{46}$ Por. tamże, Statistischer Bericht über die Missionspfarrei Osterode pro 1878.

${ }^{47}$ Por. tamże (3.01.1880). 
wynosiła 1100 (z czego 500 osób w Ostródzie). Do wielowyznaniowej szkoły chodziło 85 katolików, natomiast do innych szkół protestanckich $80^{48}$. Pięć lat później w opisywanej parafii żyło 1233 katolików, w tym 649 w Ostródzie. Do powyższej placówki należało 60 rodzin katolickich ${ }^{49}$.

Na podstawie spisu ludności z 1 grudnia 1900 roku można stwierdzić, że w omawianej placówce duszpasterskiej mieszkało 2105 parafian (z czego w Ostródzie - 1389 osób) oraz stacjonowało 648 katolickich żołnierzy. Dzieci objętych obowiązkiem nauczania było wówczas $380^{50}$. W 1904 roku w miejscowej szkole elementarnej dla chłopców uczyło się 118 katolickich dzieci, zaś w szkole dla dziewcząt - 102 dzieci. Do gimnazjum uczęszczało 36 katolickich uczniów, natomiast do wyższej szkoły żeńskiej (Höhere Mädchenschule) - 14 katolickich uczennic ${ }^{51}$.

W 1916 roku na terenie parafii mieszkało ok. 3450 katolików (w Ostródzie - 2400 wraz ze stacjonującymi żołnierzami). Odnotowano w tym czasie ok. 520 uczniów objętych obowiązkiem nauczania (w tym 250 z Ostródy). Warto dodać, że ok. 100 uczniów nie uczęszczało na katolickie lekcje religii. W ostródzkim gimnazjum uczyło się 36 osób wyznania katolickiego, natomiast w liceum $-37^{52}$. W 1923 roku parafia liczyła 3420 katolików ${ }^{53}$, zaś trzy lata później - ok. 2700 (bez stacjonujących żołnierzy i robotników sezonowych) ${ }^{54}$. Liczba katolików w 1929 roku wzrosła do $2750^{55}$, natomiast w 1932 roku - do 2 821. Na terenie parafii przebywało czasowo 30-40 katolików ${ }^{56}$. W misyjnym zestawieniu statystycznym z 1935 roku podano, że do ostródzkiej parafii należało 2800 katolików $^{57}$. Rok przed wybuchem drugiej wojny światowej parafia ostródzka liczyła 2780 wiernych. Poza tym na jej obszarze przebywało $40-50$ katolików spoza parafiii ${ }^{58}$.

\section{WYBRANE ASPEKTY DUSZPASTERSKIE}

Posługa duszpasterska duchowieństwa wpływała na pogłębienie najważniejszych aspektów życia religijnego mieszkańców Ostródy i okolic. Od chwili erygowania placówki misyjnej w tym mieście życie sakramentalne rozwijało się dynamiczne, co obrazuje poniższa tabela.

\footnotetext{
${ }^{48}$ Por. tamże (20.02.1884).

${ }^{49}$ Por. tamże, Missionsbericht v. J. 1888.

${ }^{50}$ Por. tamże, Missionsbericht vom Jahre 1902.

${ }^{51}$ Por. Schematismus des Bistums Culm mit dem Bischofssitze in Pelplin 1904, dz. cyt.,
} s. 397. W 1912 roku liczba polskich robotników sezonowych w powiecie ostródzkim przekraczała 3000 (por. Arch. Paderborn, Teczka: Osterode [25.01.1912]).

${ }_{52}^{5}$ Por. tamże, Missionsbericht 1916.

${ }^{53}$ Por. tamże, Missionsbericht 1923.

${ }^{54}$ Por. tamże, Missionsbericht 1926.

${ }^{55}$ Por. tamże, Missionsbericht 1929.

${ }^{56}$ Por. tamże, Missionsbericht 1932.

${ }^{57}$ Por. tamże, Missionsbericht 1935.

${ }^{58}$ Por. tamże, Missionsbericht 1938. 
Tabela 1. Liczba chrztów, ślubów, pogrzebów, osób przystępujących do Pierwszej Komunii św. oraz udzielonych Komunii św. w latach 1854-1862 w placówce katolickiej w Ostródzie

\begin{tabular}{|c|c|c|c|c|c|}
\hline Lata & Chrzty & Śluby & Pogrzeby & $\begin{array}{c}\text { Pierwsza } \\
\text { Komunia św. }\end{array}$ & $\begin{array}{c}\text { Komunia św. } \\
\text { wielkanocna }\end{array}$ \\
\hline 1854 & 21 & 1 & 13 & 11 & 332 \\
\hline 1855 & 22 & 11 & 19 & 31 & 502 \\
\hline 1856 & 37 & 11 & 31 & 22 & 553 \\
\hline 1857 & 51 & 11 & 30 & 56 & 720 \\
\hline 1858 & 42 & 11 & 19 & 52 & 740 \\
\hline 1859 & 56 & 7 & 31 & 40 & 740 \\
\hline 1860 & 37 & 12 & 24 & 34 & 818 \\
\hline 1861 & 37 & 13 & 13 & 25 & 690 \\
\hline 1862 & 35 & 7 & 19 & 38 & 716 \\
\hline
\end{tabular}

Źródło: Arch. Paderborn, Teczka: Osterode (3.01.1863).

Z powyższej tabeli wynika, że w początkowym okresie działalności stacji misyjnej w Ostródzie udzielono najmniej sakramentów i sakramentaliów. W drugiej połowie lat pięćdziesiątych XIX wieku odnotowano najwięcej chrztów (w 1859 - 56), ale i najwięcej pogrzebów (w 1856 i 1859 - 31). Najmniej pogrzebów zgłoszono w 1854 i w 1861 roku - 13. Do pierwszej Komunii św. najwięcej osób przystapiło w 1857 roku - aż 56. W 1860 roku udzielono najwięcej Komunii św. - 818. Spadek liczby przyjmowanych sakramentów i sakramentaliów w latach sześćdziesiątych XIX wieku był związany prawdopodobnie $\mathrm{z}$ erygowaniem nowych stacji misyjnych na obszarach podporządkowanych dotąd placówce duszpasterskiej w Ostródzie.

Pod koniec lat sześćdziesiątych XIX wieku w niedzielnych i świątecznych nabożeństwach uczestniczyło ok. 220 osób $^{59}$. W 1874 roku ochrzczono 52 dzieci (z czego 17 z rodzin mieszanych wyznaniowo i 7 panieńskich) oraz asystowano przy 15 ślubach (w tym 5 par mieszanych). Zmarło w tym czasie 23 katolików (w tym 17 dzieci), którzy (z wyjątkiem 3 zmarłych) zostali pochowani na ostródzkim cmentarzu katolickim. Do pierwszej Komunii św. przystapiło 4 października 1874 roku - 27 dzieci $(13$ z rodzin mieszanych) ${ }^{60}$. W 1877 roku odnotowano 56 chrztów (w tym 18 z rodzin mieszanych oraz 6 panieńskich), 10 ślubów (2 pary mieszane) oraz 23 pogrzeby (w tym 18 dzieci) ${ }^{61}$. Rok później zgłoszono 61 chrztów (w tym 21 $\mathrm{z}$ rodzin mieszanych i 2 panieńskie), 13 ślubów (w tym 6 małżeństw mieszanych) i 26 pogrzebów (w tym 24 dzieci) ${ }^{62}$.

\footnotetext{
${ }^{59}$ Por. tamże (1868).

${ }^{60}$ Por. tamże, Statistischer Bericht über die Missions-Pfarrei Osterode pro 1874.

${ }^{61}$ Por. tamże, Statistischer Bericht über die Missionspfarrei Osterode pro 1877.

${ }^{62}$ Por. tamże, Statistischer Bericht über die Missionspfarrei Osterode pro 1878.
} 
W 1879 roku udzielono ok. 1500 Komunii św., a w okresie wielkanocnym -701 . Na niedzielne nabożeństwa uczęszczało 170-200 osób. W tym czasie odnotowano 68 chrztów, 11 ślubów i 38 pogrzebów ${ }^{63}$. W 1882 roku ochrzczono 58 dzieci (w tym 23 z rodzin mieszanych wyznaniowo i 8 panieńskich), pobłogosławiono 16 związków małżeńskich (w tym $9 \mathrm{z}$ osobami innych wyznań) oraz pochowano 26 zmarłych (w tym 17 dzieci) ${ }^{64}$. W następnym roku zgłoszono 63 chrzty, 9 ślubów i 30 pogrzebów. Udzielono we wspomnianym okresie 1500 Komunii św., a w czasie wielkanocnym $650^{65}$. Pięć lat później uczestniczyło w niedzielnych nabożeństwach ok. 300 osób. Udzielono na przestrzeni roku 1500 Komunii św., a w okresie wielkanocnym - 750. Ochrzczono wówczas 64 dzieci, pobłogosławiono 4 związki małżeńskie i przeprowadzono 29 pogrzebów ${ }^{66}$. W 1901 roku na niedzielne nabożeństwa przychodziło przeciętnie 400-500 osób (nie uwzględniono dzieci oraz żołnierzy). Odnotowano 81 chrztów, 8 ślubów i 48 pogrzebów. Rok później w okresie wielkanocnym udzielono 1133 Komunie św. osobom cywilnym oraz 523 - żołnierzom ${ }^{67}$.

W 1915 roku zgłoszono 93 chrzty (w tym 6 z rodzin mieszanych wyznaniowo oraz 9 panieńskich), 8 ślubów (w tym 3 z osobami innych wyznań) oraz 57 pogrzebów ludności cywilnej i 7 żołnierzy. W następnym roku uczęszczało na niedzielne nabożeństwa łącznie ze stacjonującymi żołnierzami ok. 1000 osób $^{68}$. W 1920 roku ochrzczono 107 dzieci (w tym 17 $\mathrm{z}$ rodzin mieszanych i 13 panieńskich), w 1921 roku -98 (w tym 11 z rodzin mieszanych i 9 panieńskich), a w 1922 roku - 110 (w tym 15 z rodzin mieszanych i 7 panieńskich). Liczba sakramentalnych związków małżeńskich wynosiła w 1920 roku - 29 (w tym 9 mieszanych: 4 z katolickim narzeczonym), w 1921 roku - 25 (w tym 7 mieszanych: 3 z katolickim narzeczonym) i w 1922 roku - 23 (w tym 7 z katolickim narzeczonym). Komunię św. wielkanocną przyjęły w 1920 roku - 1623 osoby, w 1921 roku - 1 648, a w 1922 roku - 1723 roku $^{69}$.

W parafii ostródzkiej działały liczne organizacje i stowarzyszenia katolickie, m.in.: Bractwo Serca Jezusowego (założone 17 czerwca 1893), Towarzystwo św. Elżbiety (1905), Caritas, Katolickie Towarzystwo Pogrzebowe (1903), Towarzystwo Matek (1919), Towarzystwo Młodzieży Męskiej (Jungmännerverein; założone w 1911, rozwiązane przez władze hitlerowskie w 1934), Sodalicja Mariańska Młodzieży Żeńskiej (Marianische JungfrauenKongregation; 1922), Związek Czeladniczy (1894), Towarzystwo św. Karola Boromeusza, Katolicki Związek Kobiet Niemieckich (1924), Towarzy-

\footnotetext{
${ }^{63}$ Por. tamże (3.01.1880).

${ }^{64}$ Por. tamże, Statistischer Bericht über die Missionspfarrei Osterode pro 1882.

${ }^{65}$ Por. tamże (20.02.1884).

${ }^{66}$ Por. tamże, Missionsbericht v. J. 1888

${ }^{67}$ Por. tamże, Missionsbericht vom Jahre 1902.

${ }^{68}$ Por. tamże, Missionsbericht 1916.

${ }^{69}$ Por. tamże, Missionsbericht 1923.
} 
stwo św. Franciszka Ksawerego, Towarzystwo Dzieciątka Jezus, Niemiecka Siła Młodzieńcza (Deutsche Jugendkraft; 1920, przekształcone prawdopodobnie w Towarzystwo Sportowe), Towarzystwo św. Cecylii oraz Stowarzyszenie świętych Bonifacego i Wojciecha ${ }^{70}$.

W 1926 roku celebrowano w ostródzkiej świątyni Msze św. niedzielne o godz. 7.00, 8.00 i 9.30, zaś w ciagu tygodnia o 6.45 i 7.00. W Szczepankowie odprawiano nabożeństwa $\mathrm{w}$ drugą niedzielę miesiąca o 9.30, zaś $\mathrm{w}$ Miłomłynie - w czwartą niedzielę miesiąca również o godz. $9.30^{71}$. W 1932 roku informowano w zestawieniu statystycznym parafii, że kaplica miłomłyńska znajdowała się w budowie. Nabożeństwa sprawowano w tym czasie $\mathrm{w}$ pomieszczeniu piwnicznym nadleśnictwa ${ }^{72}$.

\section{FINANSE PARAFII}

Dziewiętnastowieczna budowa kościoła, domu parafialnego wraz z pomieszczeniami szkolnymi oraz stajni kosztowała 13454 talary $^{73}$. W 1868 roku kapitał fundacji kościelnych i proboszczowskich ulokowany w papierach wartościowych opiewał na kwotę 6035 talarów 19 srebrnych groszy i 4 fenigów. Duszpasterz pobierał wówczas roczne wynagrodzenie składające się m.in. z dotacji Stowarzyszenia św. Bonifacego w Pelplinie -240 talarów oraz odsetek z kapitału (prawdopodobnie z tzw. kapitału proboszczowskiego) - 178 talarów $^{74}$. W 1872 roku proboszczowi ostródzkiemu na poczet rocznej pensji wypłacano: dotację ze Stowarzyszenia św. Bonifacego - 240 talarów, odsetki z tzw. kapitału proboszczowskiego - 254 talary 28 srebrnych groszy i 3 fenigi, dochody z fundacji mszalnych - 132 talary 11 srebrnych groszy i 10 fenigów. We wspomnianym okresie wspólnota wiernych płaciła jedynie tzw. dziesięcinę osobistą, ponieważ w większości miejscową społeczność katolicką tworzyli robotnicy, którzy nie byli w stanie przekazywać na rzecz parafii dodatkowych donacji ${ }^{75}$.

W 1877 roku poza kapitałem wynikającym z posiadanych dóbr ziemskich, parafia władała 10 886,77 markami kapitału w ramach różnych fundacji, z których część - dla większego zysku - pożyczono pod pięcioprocentowy zastaw hipoteczny. Miejscowy duszpasterz otrzymywał rocznie $\mathrm{z}$ fundacji mszalnych 352,45 marki, za które sprawował 160 Mszy św. Z będącego własnością parafii tzw. kapitału proboszczowskiego o wartości 13771 marek, ulokowanego w papierach wartościowych oprocentowanych rocznie na $4 \%, 5 \%$ i $6 \%$, proboszcz pobierał odsetki wynoszące 764,83 marki.

\footnotetext{
${ }^{70}$ Por. K. Bürger, Das katholische Kirchenwesen im Kreis Osterode (2), dz. cyt., s. 3.

${ }^{71}$ Por. Arch. Paderborn, Teczka: Osterode, Missionsbericht 1926.

${ }^{72}$ Por. tamże, Missionsbericht 1932.

${ }^{73}$ Por. Schematismus des Bistums Culm mit dem Bischofssitze in Pelplin 1904, dz. cyt., s. 396.

${ }^{74}$ Por. Arch. Paderborn, Teczka: Osterode (1868).

${ }^{75}$ Por. tamże (5.04.1872).
} 
Oprócz tego diecezjalny komitet Stowarzyszenia świętych Bonifacego i Wojciecha w Pelplinie przekazywał proboszczowi roczną zapomogę 720 marek. Nauczyciel otrzymywał wynagrodzenie o wartości 975 marek z funduszy komunalnych, ponieważ ostródzka szkoła stanowiła własność mia$\mathrm{sta}^{76}$. W 1880 roku kapitał kościelny wynosił 300 marek, natomiast proboszczowski - 13 793,75 marki. Na roczną pensję proboszcza składały się w tym czasie następujące dochody: z fundacji mszalnych - 352,45 marki, odsetki z tzw. ostródzkiego kapitału proboszczowskiego - 693,71 marki, z fundacji Maximiliana - ok. 66 marek, z iura stole - 200 marek, z tzw. dziesięciny osobistej - 25 marek, z diecezjalnego Stowarzyszenia świętych Bonifacego i Wojciecha w Pelplinie - 870 marek. W sumie ostródzki proboszcz pobierał roczną pensję o wartości 2 205,16 marek. Pensja nauczyciela w tym czasie pozostawała na poziomie 975 marek. Prawdopodobnie otrzymywał on rocznie jako organista dodatkowo ok. 300 marek, z czego 96 marek pochodziło z diecezjalnego komitetu Stowarzyszenia świętych Bonifacego i Wojciecha w Pelplinie ${ }^{77}$.

W 1884 roku kapitał kościelny wynosił 300 marek, natomiast proboszczowski - 17 078,75 marek. W ramach rocznej pensji proboszcz otrzymywał w tym okresie: z fundacji mszalnych - 486,03 marek, z tzw. ostródzkiego kapitału proboszczowskiego oraz fundacji Maximiliana - 922,11 marki, z iura stole - ok. 160 marek, z tzw. dziesięciny osobistej - ok. 40 marek oraz z diecezjalnego komitetu Stowarzyszenia świętych Bonifacego i Wojciecha w Pelplinie - 870 marek. W sumie proboszcz zarabiał 2 478,14 marek. Nauczyciel otrzymywał wówczas 975 marek z funduszy komunalnych, 120 marek dopłaty mieszkaniowej ze Stowarzyszenia św. Bonifacego w Paderborn oraz 250 marek jako organista i kościelny. Roczna pensja nauczyciela wynosiła w sumie 1345 marek $^{78}$. W 1888 roku odnotowano 300 marek kapitału kościelnego oraz 10293 marki kapitału proboszczowskiego. W porównaniu z poprzednimi latami fundusz ten zmalał o 6825 marek. Powyższe pieniądze zostały częściowo bądź całkowicie utracone, w związku z czym toczyło się w tej sprawie postępowanie procesowe. Wartość wszystkich nieruchomości parafialnych określano na 54505 marek. Warto wspomnieć, że parafia nie posiadała $\mathrm{w}$ tym czasie żadnego zadłużenia. Na poczet rocznej pensji proboszcz otrzymywał odsetki z fundacji mszalnych - 463,17 marki, z fundacji Maximiliana - ok. 60 marek, z iura stole - 50 marek, ze składek miejscowej wspólnoty katolickiej - 30 marek, z diecezjalnego komitetu Stowarzyszenia świętych Bonifacego i Wojciecha w Pelplinie - 870 marek i prawdopodobnie $\mathrm{z}$ funduszu proboszczowskiego (oraz zapewne $\mathrm{z}$ dofinansowania ze strony państwa) - 521,92 marek. W sumie pensja proboszcza kształtowała się na poziomie 1995,09 marek. Zobowiązania nałożone na

\footnotetext{
${ }^{76}$ Por. tamże (15.01.1877).

${ }^{77}$ Por. tamże (3.01.1880).

${ }^{78}$ Por. tamże (20.02.1884).
} 
wspólnotę katolicką w ramach tzw. dziesięciny osobistej, kolekt kościelnych oraz kasy budowlanej przynosily rocznie ok. 250 marek $^{79}$.

W 1902 roku kapitał kościelny wzrósł nieznacznie do 309,50 marek, proboszczowski osiagnął poziom 16 567,02 marek (być może odzyskano w postępowaniu sądowym utracone wcześniej fundusze), zaś fundacji mszalnych wynosił 14625,14 marek. Należy nadmienić, że na powyższy kapitał mszalny składało się 17 fundacji, w ramach których proboszcz odprawiał 163 Msze św. Na roczną pensję proboszcza składały się dochody z tzw. nieobciążonych funduszy (np. ostródzkiego funduszu proboszczowskiego) - 647,12 marek, z fundacji mszalnych - 410,91 marek, z iura stole 636 marek, z dotacji państwowych - 508 marek, z diecezjalnego Stowarzyszenia świętych Bonifacego i Wojciecha w Pelplinie - 362 marki. W sumie proboszcz otrzymywał 2 564,03 marki. Należy nadmienić, że ostródzkich parafian opodatkowano z myślą o planowanej rozbudowie kościoła $(20 \%$ wartości podatku dochodowego ${ }^{80}$. Na utrzymanie wikariusza parafia przeznaczała w 1912 roku - 900 marek rocznie, natomiast na pensję dla 5 sióstr zakonnych -800 marek $^{81}$.

W 1916 roku w ramach wynagrodzenia proboszcz otrzymywał łącznie 110 marek tygodniowo z funduszy państwowych (za lekcje religii w gimnazjum) i miejskich (za lekcje religii w liceum). Ponadto na jego roczną pensję składały się dochody $\mathrm{z}$ nieobciążonych funduszy (prawdopodobnie $\mathrm{z}$ tzw. funduszu proboszczowskiego) - 705,34 marek, z fundacji mszalnych 264,40 marki, z iura stole - 1000 marek, z dotacji państwowych - 1600 marek, z diecezjalnego komitetu Stowarzyszenia świętych Bonifacego i Wojciecha w Pelplinie - 240 marek. Wspomniane stowarzyszenie dopłacało ponadto 600 marek do rocznej pensji nauczyciela religii, który dojeżdżał do innych miejscowości położonych na terenie parafii ostródzkiej. Miejscowa wspólnota katolicka była obciążona podatkiem kościelnym, który pobierano w wysokości $22,2 \%$ od wartości podatku dochodowego. Kapitał kościelny wynosił wówczas 309,50 marek, proboszczowski - 16 567,02 marek, zaś fundacji mszalnych - 19 225,14 marek. Zadłużenie z racji rozbudowy kościoła stanowiło 40000 marek, natomiast z tytułu budowy domu klasztornego sióstr elżbietanek - 22000 marek $^{82}$. W 1923 roku zadłużenie parafii w porównaniu z 1916 rokiem nie uległo zmianie. Na początku lat dwudziestych XX wieku pobierano od parafian podatek kościelny w wysokości $10 \%$ od wartości podatku dochodowego ${ }^{83}$.

W 1926 roku, a zatem bezpośrednio po okresie wielkiej inflacji w Niemczech, zarówno kapitał funduszy kościelnych, proboszczowskich, jak i mszalnych nie był wymieniany w zestawieniach statystycznych. Było to

\footnotetext{
${ }^{79}$ Por. tamże, Missionsbericht v. J. 1888.

${ }^{80}$ Por. tamże, Missionsbericht vom Jahre 1902.

${ }^{81}$ Por. tamże (25.01.1912).

${ }^{82}$ Por. tamże, Missionsbericht 1916.

${ }^{83}$ Por. tamże, Missionsbericht 1923.
} 
spowodowane prawdopodobnie wspomnianą hiperinflacją, przez która dotychczasowe papiery wartościowe straciły wartość. W tym czasie pobierano od parafian podatek kościelny w wysokości $15 \%$ od wartości podatku dochodowego. Zakładane wpływy z tego tytułu miały wynieść w 1925 roku - 3 000 marek, natomiast ściagalność podatków osiagnęła poziom 2840 marek. Zadłużenie domu klasztornego w 1926 roku zmalało do 5248 marek $^{84}$. W 1929 roku na poczet podatku kościelnego pobierano od parafian $10 \%$ wartości podatku gruntowego oraz $10 \%$ wartości podatku dochodowego, co dawało łącznie ok. 3000 marek w skali roku. Parafia czerpała dochód również z tzw. Kirchgeld, czyli podatku obejmującego wszystkich członków wspólnoty katolickiej, którzy ukończyli osiemnasty rok życia i podlegali państwowemu opodatkowaniu $\mathrm{z}$ racji odpowiednich dochodów lub posiadanych gruntów. Przychody z tego podatku w 1928 roku opiewały na 138 marek $^{85}$.

W 1932 roku podniesiono stawki podatku kościelnego do $12 \%$ wartości podatku dochodowego i gruntowego. Dochody z tego podatku miały przynieść w 1931 roku - 4888 marek, jednak faktyczne wpływy wyniosły 4280 marek. Z tzw. Kirchgeld otrzymano jedynie 85 marek. Warto zaznaczyć, że parafia posiadała zadłużenie w wysokości 4500 marek $^{86}$. W połowie lat trzydziestych XX wieku utrzymano dotychczasowe stawki na rzecz podatku kościelnego, do których doliczono także $12 \%$ wartości podatku od działalności przemysłowej i handlowej. W 1934 roku przewidywane korzyści materialne $\mathrm{z}$ tego podatku miały zasilić kasę kościelną o sumę 3928 marek, jednak faktyczny dochód wyniósł 3715 marek. W ramach tzw. Kirchgeld otrzymano 420 marek. Zadłużenie parafii wzrosło do 4900 marek $^{87}$.

Rok przed wybuchem drugiej wojny światowej stawki podatku kościelnego obniżono do $8 \%$ od wartości podatku dochodowego i $10 \%$ od wartości podatku gruntowego. W 1937 roku przewidywano wpływy z tego podatku w wysokości 4108 marek, jednak otrzymano jedynie 3800 marek. Z tzw. Kirchgeld uzyskano w tym czasie 200 marek, natomiast zadłużenie zredukowano do 4368 marek $^{88}$.

\footnotetext{
${ }^{84}$ Por. tamże, Missionsbericht 1926.

${ }^{85}$ Por. tamże, Missionsbericht 1929.

${ }^{86}$ Tamże, Missionsbericht 1932.

${ }^{87}$ Tamże, Missionsbericht 1935.

${ }^{88}$ Tamże, Missionsbericht 1938.
} 


\section{CATHOLIC PARISH IN OSTRÓDA IN THE $19^{\text {th }}$ AND THE FIRST HALF OF THE $20^{\text {th }}$ CENTURY}

\section{Summary}

The first Mass since the Reformation times was celebrated in Ostróda in 1834. From that time, the rector from Grabowo came to the said town twice a year with pastoral services. Considering the increasing number of worshippers, the authorities of the Bishopric of Culm decided to appoint a permanent priest in Ostróda; this function was assigned to Stephan Keller on $27^{\text {th }}$ September 1853. On 31 May 1855, he founded a private Catholic school, which was given the status of a public school on $2^{\text {nd }}$ October 1860. One of the greatest tasks which awaited the priest of Ostróda was the building of a temple. The project was prepared by Vinzenz Statz, an architect. The foundation stone of the new temple was laid on $28^{\text {th }}$ August 1856. The consecration of the new church took place on $20^{\text {th }}$ December 1857. In 1859, a plot of land was bought; it was meant to be a Catholic cemetery. A full-fledged Catholic parish was founded in Ostróda on $10^{\text {th }}$ February 1860 . Eight years later, a presbytery was built, with apartments for the rector and the organist. With regard to the increasing number of worshippers, the temple was extended in 1912-1913. In that time, the nave was elongated by two more spans. A chancel with annexes, pinnacles topping the gables and a tower were built. The project of the works was developed by an architect from Königsberg - Fritz Heitmann. The temple was consecrated on $1^{\text {st }}$ June 1923 by the bishop of Warmia Augustyn Bludau to honour the Immaculate Conception of the Blessed Virgin Mary. From December 1922, the parish of Ostróda was connected to the Diocese of Warmia. In 1868, 1143 Catholics belonged to the said institution, in $1900-2105$, and in $1938-2780$. In the area of the parish, numerous organisations and associations were active, including the Saint Cecilia Association and the Fraternity of the Sacred Heart of Jesus. The $19^{\text {th }}$ century construction of the church together with a parish house and a stable cost 13,454 thalers, and the $19^{\text {th }}$ century extension of the religious building - over 100,000 marks. The parish was financially supported by the Saint Boniface and Adalbert Association in Pelplin.

Keywords:

Catholic diaspora, Bishopric of Culm, Diocese of Warmia, religious buildings, church buildings, East Prussia, West Prussia 
